\title{
Confidence in impression formation as a function of favorableness of information and expertness of source
}

\author{
JOSEPH F. KERSEY, EDGAR O'NEAL, and RAYMOND PLEDGER* \\ Tulane University, New Orleans, La. 70118
}

Sixty undergraduates were led to believe that either a highly competent clinician (high expert communicator) or a clinical psychologist of questionable ability (low expert communicator) had filled out an adjective check list describing a stimulus person in either favorable or unfavorable terms. According to prediction, Ss who had received information from the high expert source described themselves as more confident in the information and felt less desire for additional information to make "an important decision" regarding the stimulus person. Contrary to prediction, however, unfavorable information led to less confidence and greater desire for additional information than did favorable information.

One often finds that one is called upon to form an impression about another person's dispositions based upon a limited amount of observed behavior or reported information. Jones \& Davis (1965) suggest a theoretical construct, "correspondence," defined as the degree to which an inference describes both an act and the underlying characteristics which dispose the actor to perform in such a manner. It is frequently operationalized by asking the $O$ either his amount of confidence in his impressions of the actor or his desire for additional information about the actor before making an important decision regarding him (e.g., Jones, Davis, \& Gergen, 1961). Jones \& Davis $(1965$, p. 228) postulate that correspondence declines as the assumed social desirability of an act increases.

There is some evidence that suggests that this line of reasoning may be applied to cases in which an individual does not see (or hear) the act performed but is provided with direct information about the attributes of the other person (e.g., Briscoe, Woodyard, \& Shaw, 1967; Rickney, McClelland, \& Shimkunas, 1967). The rationale offered by Briscoe et al appears applicable to most of the reports. They suggest that favorable information about a person may reveal merely his performance of societal expectations; unfavorable information, on the other hand, implies behavior which runs contrary to such general normative prescriptions.

Who is providing information about the other person is also an important determinant of one's confidence in impressions of the other person. Rosenbaum (1967) and Rosenbaum \&

* Now at the University of Texas, Austin, Tex. 78712 .
Levin (1968) report that Ss responded differently to adjective check lists provided by sources varying in "value." The latter investigators offered evidence that the "credibility" of the source of evaluative information affects confidence in that information. Credibility apparently contained elements of expertness and trustworthiness, although no attempt was made to specify its possible components.

This study was conducted to test the hypothesis that confidence in impressions of another person based on unfavorable information would be higher than confidence in impressions based on favorable information. Moreover, it was hypothesized that the difference in confidence in impressions based on favorable and unfavorable information would be greater when the source was low in expertness. DESIGN AND OVERVIEW

The Ss were 60 students in introductory psychology who received information about two stimulus persons from a source identified as either high or low in expertness. For each $S$, the information provided regarding one of the stimulus persons was favorable and that regarding the other was unfavorable. All Ss then indicated the degree of their confidence in the information and their desire for additional information about each stimulus person. The design, therefore, was a 2 (expertness of source) by 2 (favorability of information) factorial, with the latter variable being within $S$.

\section{MATERIALS AND PROCEDURE}

A booklet of four pages was presented to each $S$. Pages 1 and 2 consisted of eight 9-point scales from Anderson's (1968) list of personality trait words entitled Person Evaluation Profile (PEP). Within each of the two PEPs, four of the trait words were negative, i.e., had an Anderson rating of less than 2.00, and the other four were positive, i.e., had an Anderson rating of higher than 4.00. (The mean Anderson rating for the trait words was approximately 3.00 , or neutrality.) The endpoints of the scales were labeled exceptionally characteristic and not characteristic. Instructions established the clinical usefulness of PEP, the need to evaluate this usefulness, and the need to make the application of PEP more general, i.e., independent of the rater's outside skills.

The Ss received premarked (or previously rated) PEPs, clearly identified as being from the same source. Two types of PEPs were produced: (1) favorable, for which the positive traits had a mean rating of 7 on the 9-point scale and the negative items had a mean rating of 3 ; and (2) unfavorable, for which the positive traits had a mean rating of 3 and the negative items had a mean rating of 7 . Two sources for the PEPs were used: (1) a "less than successful", psychologist with no experience with the PEP, and (2) a "highly successful" psychologist with extensive training with the PEP. The Ss were requested to "get an accurate impression" of both stimulus persons.

After study of the PEPs, the Ss turned to the third page of the test booklet, which consisted of 2-point scale items designed to indicate confidence in the previous information, two 9-point scale items to indicate felt need of additional information, and one forced-choice question to indicate preference for the favorable or unfavorable PEP.

The fourth page consisted of several items to test the S's memory of the stimulus items (PEP). Each question was multiple choice. These items in conjunction with debriefing confirmed the $S$ 's understanding of the experiment and his naivete.

RESULTS AND DISCUSSION

The mean ratings for confidence in information are presented in Table 1. As expected, Ss who received information from a high expert source expressed more confidence in that information than did Ss whose source was low expert $(F=8.34, \mathrm{df}=1 / 58$,

Table 1

Mean Confidence in Information

\begin{tabular}{llll}
\hline \multirow{2}{*}{$\begin{array}{c}\text { Favorability } \begin{array}{l}\text { of } \\
\text { of }\end{array} \\
\text { Information }\end{array}$} & \multicolumn{3}{l}{ Expertness of Source } \\
\cline { 2 - 3 } & High & Low & \\
\hline Favorable & 5.13 & 4.07 & 4.60 \\
Unfavorable & 4.70 & 3.57 & 3.82 \\
& 4.92 & 3.82 &
\end{tabular}

Note-Thirty Ss per cell. Higher scores indicate more confidence. 
p $<.01)$. However, contrary to prediction, confidence was higher for favorable information than for unfavorable $(F=6.27, \quad d f=1 / 58$, $\mathrm{p}<.05$ ). Also contrary to prediction, no significant interaction was detected. As indicated in Table 2, Ss desired more additional information for stimulus persons described unfavorably than for those described favorably $(F=8.09, \mathrm{df}=1 / 58$, $p<.01$ ), a finding in line with the unexpected results of the effect of favorability upon confidence. Although an examination of Table 2 indicates that $S s$ for whom the stimulus persons were described by the low expert source desired more additional information than did the other Ss, this difference did not approach significance. Neither was any significant interaction detected between favorability of information and expertness of source.

of the $30 \mathrm{Ss}$ in the high-credibility source condition, 20 preferred the favorable information; $21 \mathrm{Ss}$ in the other condition expressed a similar preference in response to the forced-choice item in the questionnaire. A simple $z$ transformation of the data for favorable vs unfavorable information yielded $z=-2.864 \quad(\mathrm{p}<.004)$. The preference for favorable over nonfavorable information for $S s$ in both conditions appears to be substantiated.

The results appear to confirm expectations concerning the effects of source expertness, but not the hypothesis concerning the effects of information favorability upon confidence. However, Ss' comments during debriefing indicated that they may have interpreted the question: "How confident are you that your impression is accurate?" to be a question of predictability of behavior. If, indeed, the dependent measure tested for what sort of information

Table 2

Mean Desire for More Information

\begin{tabular}{llll}
$\begin{array}{c}\text { Favorability } \begin{array}{c}\text { Ex } \\
\text { of }\end{array} \\
\text { Information }\end{array}$ & \multicolumn{2}{l}{$\begin{array}{c}\text { Expertness } \\
\text { of Source }\end{array}$} & \\
\cline { 2 - 4 } & High & Low & \\
\hline Favorable & 5.13 & 5.77 & 5.45 \\
Unfavorable & 5.87 & 6.40 & 6.13 \\
& 5.50 & 6.08 & \\
\hline
\end{tabular}

Note-Thirty Ss per cell. Higher scores indicate greater desire for additional information.

leads to a confident prediction of future behavior rather than for what sort leads to confident attribution of personal characteristics, then describing a person in favorable terms may imply that he conforms to societal expectations and therefore will emit less "unexpected" behavior.

One further possible explanation of the unexpected effects of favorability should be mentioned. The possibility exists that the sources of information used here might, because of the specific role of the communicator, represent sources from which favorable information is more salient than unfavorable information. That is, if one views the usual duties of clinical psychologists as basically diagnosing and dealing with mental disorders (therefore usually dispensing negative information), then positive information might be considered an unusual output. It may be further argued that, in such a case, a positive evaluation might be considered more indicative of the stimulus person's characteristics. In this case, it would not be the favorability or unfavorability that would account for differences, but rather only the novelty of the information. The question to be answered here is whether or not it is more normative to pass on favorable information in our society as opposed to unfavorable.

Finally, it may be that the data force one suggestion from Jones \&
Davis (1965, p. 236) to be called into question; they suggest that experimental results showing out-of-role behavior to indicate more clearly the actor's personal characteristics are generalizable to behavior which is not governed by situational demands. The $S s$ in the present experiment did not have the opportunity to see the stimulus person act within the context of a specific role or to examine his intent. In fact, PEP was described to $S$ s in such a way as to make unlikely an inference that the stimulus person's intent could be reflected in the diagnostic. From the data presented, it appears that in making certain types of general decisions about other people, unfavorable information may be no more informative than favorable information.

\section{REFERENCES}

ANDERSON, N. H. Likeableness ratings of $\mathbf{5 5 5}$ personality-trait words. Journal of Personality \& Social Psychology. 1968, 9. 272-279.

BRISCOE, M., WOODYARD, H., \& SHAW, $M$. Personality impression change as a function of the favorableness of first impressions. Journal of Personatity, 1967. 35, 343-357.

JONES, E. E., \& DAVIS, K. E. From acts to dispositions. In L. Berkowitz (Ed.). Advances in experimental social psychology. Vol. 2. New York: Academic Press, 1965.

JONES, E. E., DAVIS, K. E., \& GERGEN, $K$. J. Role playing variations and their informational value for person perception. Journal of Abnormal \& Social Psychology, 1961,63, 302-310.

RICHEY, M. H., MCCLELLAND, L., \& SHIMKUNAS, A. M. Relative influence of positive \& negative information in impression formation and persistence. Journal of Personality \& Social Psychology, 1967, 6, 322-327.

ROSENBAUM, $M$. $E$. The source of information in impression formation. Psychonomic Science, 1967, 8, 175-176. ROSENBAUM, M. E., \& LEVIN, I. P. Impression formation as a function of source credibility and order of presentation of contradictory information. Journal of Personality \& Social Psychology, 1968, 10, 167-174. 